\title{
Proteolytic Specificity of Lactobacillus delbrueckii subsp. bulgaricus Influences Functional Properties of Mozzarella Cheese ${ }^{1}$
}

\author{
B. S. Oommen, ${ }^{\star}$ D. J. McMahon, ${ }^{\star}$ C. J. Oberg, $†$ J. R. Broadbent, ${ }^{\star}$ and M. Strickland ${ }^{\star}$ \\ Western Dairy Center \\ *Department of Nutrition and Food Sciences \\ Utah State University, Logan 84322-8700 \\ †Department of Microbiology, \\ Weber State University, \\ Ogden, Utah 84408-2506
}

\section{ABSTRACT}

Low-moisture part-skim Mozzarella cheeses were manufactured from $2 \%$ fat milk and aged for $21 \mathrm{~d}$. Treatments included cheeses made with one of three different strains of Lactobacillus delbrueckii ssp. bulgaricus in combination with a single strain of Streptococcus thermophilus. A fourth, control treatment consisted of cheeses made with only $S$. thermophilus. Although total proteolytic ability of these strains, as indicated by the $o$-phthaldialdehyde analysis, was similar in each of the three strains of $L$. bulgaricus, these strains exhibited different proteolytic specificities toward the peptide, $\alpha_{\mathrm{s} 1}-\mathrm{CN}$ (f 1-23). On the basis of their $\alpha_{\mathrm{s} 1}-\mathrm{CN}$ (f 1-23) cleavage patterns and a previously described classification, these strains were assigned to the groups I, III, and V. The objective of this study was to investigate the influence of lactobacilli proteolytic systems, based on specificity toward $\alpha_{\mathrm{s} 1^{-}}$ CN (f 1-23), on functionality of part-skim Mozzarella cheese. Moisture, fat, protein, salt-in-moisture, and moisture in nonfat substances content of cheeses made with groups I, III, and V strain were similar. Control cheese had a lower moisture content than did other treatments. Significant differences were observed in functional properties between cheeses manufactured using groups III and V strains. Cheeses made with groups I and III strains were similar in their meltability, hardness, cohesiveness, melt strength, and stretch quality. Meltability and cohesiveness increased with age, while melt strength and stretch quality decreased with age for all cheeses. Additionally, HPLC showed that total peak areas of wa-

\footnotetext{
Received December 13, 2001.

Accepted May 19, 2002.

Corresponding author: D. J. McMahon; e-mail: djm@cc.usu.edu.

${ }^{1}$ Contribution Number 7432 of the Utah Agricultural Experimental Station, Utah State University, Logan, Utah 84322-4810. Approved by the director.
}

ter-soluble peptides derived from cleavage of $\alpha_{\mathrm{s} 1}$-CN (f 1-23) by different strains of lactobacilli could be highly correlated to meltability and stretch characteristics of cheeses made with those strains.

(Key words: $\alpha_{\mathrm{s} 1}$-casein, lactic acid bacteria, watersoluble peptides, stretchability)

Abbreviation key: CI = cheese made with a Group I strain of lactobacilli, CIII = cheeses made with a Group III strain of lactobacilli, $\mathbf{C V}=$ cheeses made with a Group V strain of lactobacilli, MNFS = moisture in nonfat substance, $\mathbf{P r t}^{+}=$Proteinase-positive, Prt $^{\mathbf{d}}=$ proteinase-deficient.

\section{INTRODUCTION}

The functionality of Mozzarella cheese has traditionally been related to the extent of proteolysis that occurs during cheese ripening (Fox, 1989). This proteolysis can result from residual coagulant activity, endogenous proteinases (e.g., plasmin), or bacterial proteinases present in the cheese. Oberg et al. (1991) established that starter cultures, specifically their proteolytic ability, have a significant impact on the body, texture, and melting properties of Mozzarella cheese. Later studies investigated how proteolysis can affect the functional properties of Mozzarella cheese. For example, improved physical properties in 6-wkold reduced fat Mozzarella cheese was attributed to degradation of $\alpha_{\mathrm{s} 1} \mathrm{CN}$ (Tunick et al., 1993). Additionally, Fife et al. (1996) reported that while the rate of disappearance of $\alpha_{\mathrm{s} 1}$-CN in low fat and part-skim Mozzarella cheeses was similar, melting properties of part-skim Mozzarella were better than those of lowfat Mozzarella cheese.

Similar work in Cheddar found no correlation between the breakdown of $\alpha_{\mathrm{s}}$-CN and melt (Bogenrief and Olson, 1995). Instead, degradation of $\beta$-CN correlated with increased melting of Cheddar cheese (Bogenrief and Olson, 1995). Dave et al. (2001) postu- 
lated that meltability is influenced by continued hydrolysis of $\alpha_{\mathrm{s} 1}-\mathrm{CN}$ and $\beta$-CN into small peptides rather than the initial hydrolysis of intact proteins. As a whole, these studies suggest degradation patterns of cheese proteins, particularly $\alpha_{\mathrm{s} 1}-\mathrm{CN}$, may vary and thereby play an important role in influencing functional properties of Mozzarella cheese.

Proteinase-positive ( $\left.\mathbf{P r t}^{+}\right)$strains of starter culture provide increased melt over time in Mozzarella cheese compared with proteinase-deficient $\left(\right.$ Prt $\left.^{\mathrm{d}}\right)$ strains (Oberg et al., 1991). Proteolysis in lactococci has been extensively studied, and lactococci were originally classified into two proteinase specificity groups, $\mathrm{P}_{I}$ or $\mathrm{P}_{I I I} . \mathrm{P}_{I}$ has $\beta$-CN as its primary substrate and $\kappa-\mathrm{CN}$ to a lesser extent, while $\mathrm{P}_{I I I}$ type proteinases degrade $\alpha_{\mathrm{s} 1^{-}}, \beta-$, and $\kappa$-CN (Kunji et al., 1996). Another scheme for classifying lactococci was based on their proteolytic specificity toward the $\alpha_{\mathrm{s} 1}$-CN (f 1-23) peptide (Exterkate et al., 1993). Lactococcal proteinases have been differentiated based on their amino acid sequence in substrate binding regions. However, proteolysis in lactobacilli is not as well defined, even though proteinases in this genus also seem to exhibit a broad range of substrate specificity (Juillard et al., 1995). Recently, Oberg et al. (2002) characterized proteinase specificity in thermophilic dairy lactobacilli based on their hydrolysis of the $\alpha_{\mathrm{s} 1}$-CN (f 1-23) peptide and classified them into groups I through VII.

PAGE is commonly used to study proteolysis in cheese. This method is based on the disappearance of intact $\mathrm{CN}$ as an indicator of the extent of proteolysis. Newer methods used to monitor degradation of $\mathrm{CN}$ include HPLC, free solution capillary electrophoresis, and micellar electrokinetic capillary chromatography (Exterkate and Alting, 1993; Broadbent et al., 1998; and Oberg et al., 2002). In addition to measuring disappearance of intact $\mathrm{CN}$, these methods can also detect the generation of breakdown products. In this study we have investigated the influence of lactobacilli proteolytic systems, based on specificity toward $\alpha_{\mathrm{s} 1^{-}}$ CN (f 1-23), on protein hydrolysis and functionality of part-skim Mozzarella cheese using three different strains of $L$. delbrueckii spp. bulgaricus starter cultures.

\section{MATERIALS AND METHODS}

\section{Starter Cultures}

A weakly proteolytic strain of Streptococcus thermophillus (DS 134; DSM Food Specialties, Millville, UT) direct-to-vat starter culture was combined with one of the three different strains of $L$. delbrueckii spp. bulgaricus that were selected based on their specificity toward $\alpha_{\mathrm{s} 1}$-CN (f 1-23) for part-skim Mozzarella cheese manufacture. The three strains belonged to groups I, III, and V of the classification of Oberg et al. (2002). Total proteolysis by $o$-phthaldialdehyde analysis (Oberg et al., 2002) was similar for all three strains $(0.91 \pm 0.1)$, but they exhibited differences in specificity (Figure 1) toward $\alpha_{\mathrm{s} 1}$-CN (f 1-23). Group I cultures initially produce peptides f $1-13$ and f $14-23$, f 1-16, and f 17-23 from $\alpha_{\mathrm{s} 1}$-CN (f 1-23). The f $1-13$ peptide fragment is further broken down into $f$ 1-9 and $f$ 10-13, and $f$ 1-6 and f 7-13 peptides. Peptide fractions initially generated by group III cultures included f 1-9 and f 10-23, f 1-13 and f 14-23, and f 116 , $\mathrm{f} 1-17$, and $\mathrm{f} 17-23$. Strains of this group further hydrolyze $\alpha_{\mathrm{s} 1}$-CN (f 1-13) peptide into f 1-9 and $\mathrm{f} 10$ 13 and f 1-6 and f 7-13. Specificity of group V cultures toward $\alpha_{\mathrm{s} 1}-\mathrm{CN}$ (f 1-23) yields f 1-9 and $\mathrm{f} 10-23$ and $\mathrm{f}$ 1-16 and f 17-23 as primary products and f 1-6, f 713 , and f 14-16 as breakdown products of the f 1-16 fragment. The production of $\alpha_{\mathrm{s} 1}-\mathrm{CN}$ (f 1-17) peptides is unique to group III strains and is absent in groups I and V cultures. Strains of group V can also be distinguished from strains of groups I and III by the absence of $\alpha_{\mathrm{s} 1}-\mathrm{CN}$ (f 1-13) in the pool of proteolytic products. Cultures were grown in Sure-Set XL-II (DSM Food Specialties) overnight at $37^{\circ} \mathrm{C}$ before addition to cheese milk.

\section{Cheese Making}

Milk was standardized to $2 \%$ fat so that the $\mathrm{CN}$ to-fat ratio was approximately 1.2 , then pasteurized $\left(78^{\circ} \mathrm{C}\right.$ for $\left.29 \mathrm{~s}\right)$, cooled $\left(5^{\circ} \mathrm{C}\right)$, and stored before being used for cheese making. Milk (12 kg) was assigned randomly to four stainless steel vats and warmed to $34.5^{\circ} \mathrm{C}$; then calcium chloride $(0.02 \%)$ was added to the milk. One vat (control) was made without addition of any Lactobacillus starter. The S. thermophillus culture was added at the rate of $0.01 \%$ to the three experimental vats and at $0.02 \%$ to the control vat. A higher inoculum was used in the control vat to compensate for the absence of lactobacilli starter. Starter cultures from groups I, III, and V were added to the experimental vats at an inoculum level of $1.25 \%$.

After $30 \mathrm{~min}$ of ripening, $1.2 \mathrm{ml}$ of double-strength rennet extract (Chymax; Chr. Hansen, Inc., Milwaukee, WI) diluted 40-fold was added to the milk in each vat. When the curd was firm (approximately $20 \mathrm{~min}$ ), it was cut using $1.3-\mathrm{cm}$ knives and was allowed to heal for $10 \mathrm{~min}$. Curd was cooked to $40.5^{\circ} \mathrm{C}$ in 30 min then one-third of the whey was removed. The remaining curd and whey were held at $40.5^{\circ} \mathrm{C}$ for 45 min with periodic stirring. Whey was completely drained at a whey $\mathrm{pH}$ of 6.0 , and curd was dry stirred until the whey $\mathrm{pH}$ reached 5.3. The curd was salted 


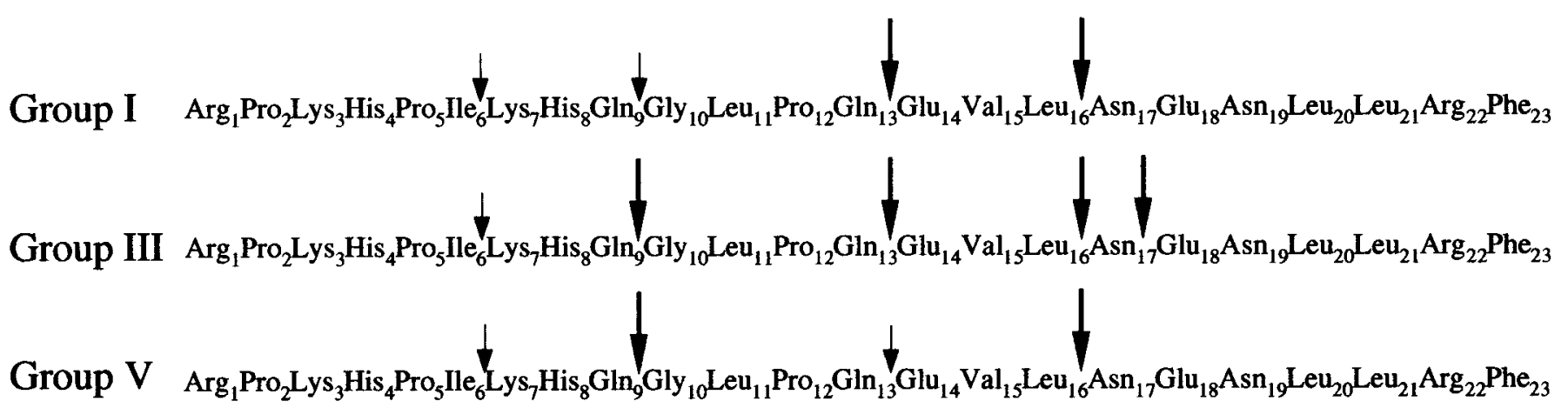

Figure 1. Breakdown pattern of $\alpha_{\mathrm{s} 1}$-CN (f 1-23) by groups I, III, and V lactobacilli. Large and small arrows represent sites of primary and secondary proteolysis, respectively.

at a rate of $0.1 \%$ of the initial milk weight and stirred for 5 min. Salted curds were stretched multi-directionally by hand for $4 \mathrm{~min}$ in a $5 \%$ brine solution maintained at $75^{\circ} \mathrm{C}$ and then molded into a ball. The maximum temperature of the curd during stretching was maintained at $63 \pm 0.5^{\circ} \mathrm{C}$. Curd balls were immersed in $2^{\circ} \mathrm{C}$ water for $1 \mathrm{~h}$, then cut into three blocks, vacuumpackaged, and stored at $4^{\circ} \mathrm{C}$ for $21 \mathrm{~d}$. The three cheeses made using groups I, III, and V lactobacilli strains were designated as CI, CIII, and $\mathbf{C V}$, respectively.

\section{Sampling}

A bulk-milk sample was drawn just before its addition to the vats for compositional analysis. The three blocks from each ball of cheese were used for functional, microbial, and peptide analysis at 7, 14, and $21 \mathrm{~d}$. Cheese composition was determined from the d7 block.

\section{Analysis}

Composition. Cheese milk was analyzed for fat, protein, lactose, and SNF with an infrared milk analyzer (Bently 2000; Bently Instruments Inc., Chaska, MN). Cheese was shredded and analyzed for fat by the modified Babcock method (Richardson, 1985), total nitrogen by the macro-Kjeldahl method, and moisture by the vacuum-oven method (AOAC, 1990). Total nitrogen was converted into total protein using a factor of 6.38. Cheeses were analyzed for salt by estimating the chloride content with a salt analyzer (model 926; Corning, Medfield, MA). Milk, whey, and cheese $\mathrm{pH}$ were measured using a $\mathrm{pH}$ meter (model 520A; Corning).

Meltability. Meltability of cheeses was measured using a UW Meltmeter (University of Wisconsin, Madison, WI) as described by Wang et al. (1998). Meltabil- ity was expressed as the percentage change in height of cheese sample (7-mm thickness and 30-mm diameter) after $10 \mathrm{~s}$ at a constant force of $0.33 \mathrm{~N}$, when heated to $65^{\circ} \mathrm{C}$.

Texture profile analysis. Hardness and cohesiveness of the cheeses were measured by texture profile analysis using a two-bite test to $80 \%$ compression (van Vliet, 1991). A force-distance curve was obtained using an Instron universal testing machine (model 5500; Instron Corp., Canton, MA) with a crosshead speed of $50 \mathrm{~mm} / \mathrm{min}$ and a $500 \mathrm{~N}$ load cell. The cheese samples tested were $1.6 \mathrm{~cm}$ in diameter and $2 \mathrm{~cm}$ in height.

Stretchability. Cheeses were tested for stretchability with the USU Stretch Test utilizing an Instron universal testing machine (model 5500; Fife et al., 2002). A cylindrical cheese sample, $30 \mathrm{~mm}$ in diameter and $30 \mathrm{~g}$ in weight, was placed in a stainless steel cup and tempered in a water bath to $65^{\circ} \mathrm{C}$. It was then placed in a hot-water jacketed sample-holder mounted on the Instron machine and maintained at $65^{\circ} \mathrm{C}$. A three-pronged probe was lowered into the melted cheese sample and the sample cup rotated into position. A tensile test was performed by pulling the probe vertically at a crosshead speed of $1,000 \mathrm{~mm} / \mathrm{min}$ until all the strands broke or the beam stroke reached the maximum and a force-distance graph was plotted. The load on the probe increases as it is lifted through the molten cheese and then decreases as the probe exits the cheese surface. Three parameters, melt strength, stretch length, and stretch quality were used to characterize cheese stretchability. Melt strength was the maximum load obtained and is related to melted cheese viscosity. Stretch length was the distance from the maximum melt strength until strand failure or the maximum beam stroke. Stretch quality was calculated as the mean value of the load exerted as the strand elongates from 7 to $15 \mathrm{~s}$ and describes the abil- 
ity of the cheese strands during pulling to remain as a cohesive mass.

Enumeration of starter bacteria. Elliker agar was used to enumerate total lactic acid bacteria, both streptococci and lactobacilli, in cheese. Lactobacilli were separately enumerated on Rogosa agar. Microbial counts were obtained by aseptically stomaching $11 \mathrm{~g}$ of cheese in $99 \mathrm{ml}$ of sterile $0.1 \%$ phosphate buffer at a speed of 530 per min for $5 \mathrm{~min}$. After stomaching, samples were serially diluted in sterile $0.1 \%$ phosphate buffer, and appropriate dilutions were plated using the pour plate method. Plates were allowed to solidify and were inverted before anaerobically (BBL GasPak System; BBL, Cockeysville, MD) incubating them at $37^{\circ} \mathrm{C}$ for $48 \mathrm{~h}$.

Determination of water-soluble peptides. Water-soluble peptides in cheese were quantified by HPLC as described by Broadbent et al. (1998) with several modifications. Cheese was shredded, and 10 $\mathrm{g}$ was homogenized in $90 \mathrm{ml}$ of cold water by stomaching for $4 \mathrm{~min}$. This solution was centrifuged and $3 \mathrm{ml}$ of the supernatant removed. The solution was filtered through a $0.2 \mu \mathrm{m}$ low-protein binding syringe filter. The filtrate was adjusted to $0.2 \mathrm{M} \mathrm{NaCl}$ by mixing 1.6 $\mathrm{ml}$ of whole extract with $0.4 \mathrm{ml}$ of $1 M \mathrm{NaCl}$ and then passed through a 30,000-Da molecular mass cut-off filter. This filter retains large proteins and peptides, particularly proteases and peptidases that may be present in the extraction, while allowing passage of small peptides into the filtrate. The filtrate was spun for $15 \mathrm{~min}$ in a microfuge and the supernatant used for HPLC analysis. A 40- $\mu$ l aliquot of supernatant was introduced onto a Vydac C8 $2.1 \times 150 \mathrm{~mm}$ reversedphase HPLC column (Vydac, Hesperis, CA) to quantify the peptides by HPLC (model 507; Beckman Instruments Inc., Fullerton, CA). As the sample preparation included water extract of cheese, the HPLC peaks show only the water-soluble peptides. The total area of the HPLC peaks is used as a measure of the total proteolysis or total water-soluble peptides in cheese.

Statistical analysis. Four replicates of cheese were made. A randomized complete block design with four treatments was used to analyze composition while a $4 \times 3$ factorial in a spilt plot was used to analyze functionality. The four culture treatments were the main plot with storage time as the subplot. PROC ANOVA and PROC MIXED of SAS software were used to analyze cheese composition and functionality, respectively (SAS, 1990). A correlation analysis was also performed using SAS software to correlate the protein degradation with changes in functional properties of cheese. Significance was declared at $P$ $\leq 0.05$.
Table 1. Composition of cheese made using streptococci alone (control) or paired with a lactobacilli strain with different proteinase specificities.

\begin{tabular}{lllll}
\hline \multirow{2}{*}{$\begin{array}{l}\text { Attributes } \\
(\%)\end{array}$} & & \multicolumn{3}{c}{ Proteinase specificity } \\
\cline { 3 - 5 } & Control & $\mathrm{I}$ & $\mathrm{III}$ & $\mathrm{V}$ \\
\hline Moisture & $44.5^{\mathrm{b}}$ & $48.4^{\mathrm{a}}$ & $47.8^{\mathrm{a}}$ & $48.1^{\mathrm{a}}$ \\
Fat & $20.5^{\mathrm{a}}$ & $19.9^{\mathrm{b}}$ & $20.0^{\mathrm{b}}$ & $20.4^{\mathrm{a}}$ \\
Protein & $28.6^{\mathrm{a}}$ & $26.6^{\mathrm{b}}$ & $26.6^{\mathrm{b}}$ & $26.8^{\mathrm{b}}$ \\
Salt & $1.25^{\mathrm{a}}$ & $1.23^{\mathrm{a}}$ & $1.18^{\mathrm{a}}$ & $1.27^{\mathrm{a}}$ \\
Salt in moisture & $2.78^{\mathrm{a}}$ & $2.54^{\mathrm{a}}$ & $2.45^{\mathrm{a}}$ & $2.64^{\mathrm{a}}$ \\
FDM $^{1}$ & $36.9^{\mathrm{c}}$ & $38.6^{\mathrm{ab}}$ & $38.3^{\mathrm{b}}$ & $39.3^{\mathrm{b}}$ \\
MNFS $^{3}$ & $56.8^{\mathrm{b}}$ & $60.4^{\mathrm{a}}$ & $59.8^{\mathrm{a}}$ & $60.4^{\mathrm{a}}$ \\
\hline
\end{tabular}

a,b,c Means in rows with no common superscripts differ $(P \leq 0.05)$.

${ }^{1}$ Fat in DM.

${ }^{2}$ Moisture in nonfat substance.

\section{RESULTS AND DISCUSSION}

\section{Composition}

Cheese milk contained $1.9 \%$ fat and $3 \%$ protein. Composition of the cheeses is shown in Table 1. Moisture content of the control cheese $(44.4 \%)$ was lower than that of cheeses made using starter culture with lactobacilli. This was attributed to longer make times for the control vats $(5 \mathrm{~h})$. Doubling the streptococcal inoculum in the control vat was insufficient to match the make times of the experimental vats $(3.5 \mathrm{~h})$. The moisture, fat, protein, fat-in-dry-matter, and moisture in nonfat substance (MNFS) levels in the three lactobacilli cheeses (CI, CIII, and CV) were not different $(P>0.05)$ (Table 1). Salt and salt-in-moisture were also not significantly different between the cheeses. Because of the difference in moisture content between the control and experimental cheeses, comparisons of the functional properties could be made only between the three treatment cheeses. The cheese $\mathrm{pH}$ varied between 5.22 and 5.1 during $21 \mathrm{~d}$ of storage.

\section{Starter Culture Enumeration}

Total lactic acid bacteria were similar in all cheeses $\left(6.5 \pm 1.5 \times 10^{8} \mathrm{cfu} / \mathrm{g}\right)$. No colonies were observed on Rogosa agar plates of control cheese through $21 \mathrm{~d}$ of storage, while the lactobacillal counts ranged between $1.6 \times 10^{6}$ and $1.1 \times 10^{8} \mathrm{cfu} / \mathrm{g}$ for the experimental cheeses. Total lactic acid bacteria and lactobacillus counts were the highest $(P \leq 0.05)$ in CV. Lactobacilli counts in CI decreased $(P \leq 0.05)$ from $8.4 \times 10^{6} \mathrm{cfu} /$ $\mathrm{g}$ at $7 \mathrm{~d}$ to $1.4 \times 10^{6} \mathrm{cfu} / \mathrm{g}$ at $21 \mathrm{~d}$. Similar decrease $(P$ $\leq 0.05$ ) in lactobacilli was also seen in CIII from 4.1 $\times 10^{6} \mathrm{cfu} / \mathrm{g}$ at $7 \mathrm{~d}$ to $5 \times 10^{5} \mathrm{cfu} / \mathrm{g}$ at $21 \mathrm{~d}$. While in CV, lactobacilli counts remained constant $(P>0.05)$ at 1.1 $\times 10^{8} \mathrm{cfu} / \mathrm{g}$ through $21 \mathrm{~d}$ of storage. 


\section{Proteolysis}

Chromatograms of the water-soluble peptides from the cheeses during $21 \mathrm{~d}$ of storage are shown in Figure 2 . In the control cheese at $d 7$, the major peaks were identified as $\alpha_{\mathrm{s} 1}$-CN (f 1-23) and $\beta$-CN (f 193-209), produced by the hydrolysis of $\alpha_{\mathrm{s} 1}-\mathrm{CN}$ and $\beta$-CN by the coagulant. At $14 \mathrm{~d}, \alpha_{\mathrm{s} 1}-\mathrm{CN}$ (f 1-23) peak area increased, reflecting continued proteolysis of intact CN. Several smaller peptides also appeared by $14 \mathrm{~d}$ of age. Hydrolysis of $\mathrm{f} \mathrm{1-23}$ by bacterial enzymes was not significant since $S$. thermophillus is only weakly proteolytic. Peak area of $f$ 1-23 continued to increase through $21 \mathrm{~d}$ of storage due to residual coagulant activity and a lack of hydrolysis by bacterial proteinases.

Higher amounts of $\alpha_{\mathrm{s} 1}$ - CN (f 1-23) and $\beta$-CN (f 193209) were seen in CI compared with the control cheese. This would be due to the faster hydrolysis of intact CN by the coagulant because of higher MNFS content (Dave et al., 2001). Other peptide peaks such as f 19 , f $1-13$, and a small amount of $\mathrm{f} 1-16$ were also present at $7 \mathrm{~d}$. Over time, there was little detectable change in the CI peaks.

In CIII, the peptide profile was very similar to CI except for a smaller peak area for $\mathrm{f} 1-23$ peptide at 7 $\mathrm{d}$ of storage. This suggests that $\mathrm{f} 1-23$ is being rapidly hydrolyzed into smaller peptides, especially f $1-13$ peptide. Over time, similar peaks were seen as in CI, with the exception of the peaks eluted at 50-min range. For both CI and CIII, major cleavage sites of f 1-23 were apparent at $\mathrm{Gln}_{13}$-Glu 14 bond. In vitro, strong and faster cleavage sites were observed at $\mathrm{Gln}_{13}-\mathrm{Glu}_{14}$ and $\mathrm{Leu}_{16}-\mathrm{Asn}_{17}$ bonds for both groups I and III lactobacilli (Figure 1). In CIII, the f 1-9 peptide peak was slightly larger than CI. This corresponds to a strong and faster (primary) cleavage site of $\mathrm{Gln}_{9}$ Gly $_{10}$ for Group III lactobacilli and a slower and weaker (secondary) hydrolysis for Group I lactobacilli as seen in vitro.

Cheeses made with group V lactobacilli were characterized by the presence of a larger $f$ 1-23 peak when compared with CI and CIII, and the peptide f 1-13 was present only at a low level. This corresponds to the specificity for group V lactobacilli, where the major cleavage products are f 1-9 and f 1-16, peaks present in CV. A similar profile was seen at both $14 \mathrm{~d}$ and 21 $\mathrm{d}$ of storage. Overall, the profile of the water-soluble peptides of the cheeses stayed relatively constant between $7 \mathrm{~d}$ and $21 \mathrm{~d}$ and could be related to the proteinase specificity of the lactobacilli portion of the starter cultures.

An indication of total proteolysis can be obtained by measuring the total peak area for all peptides in each chromatogram (Figure 3 ). The percentage of wa-
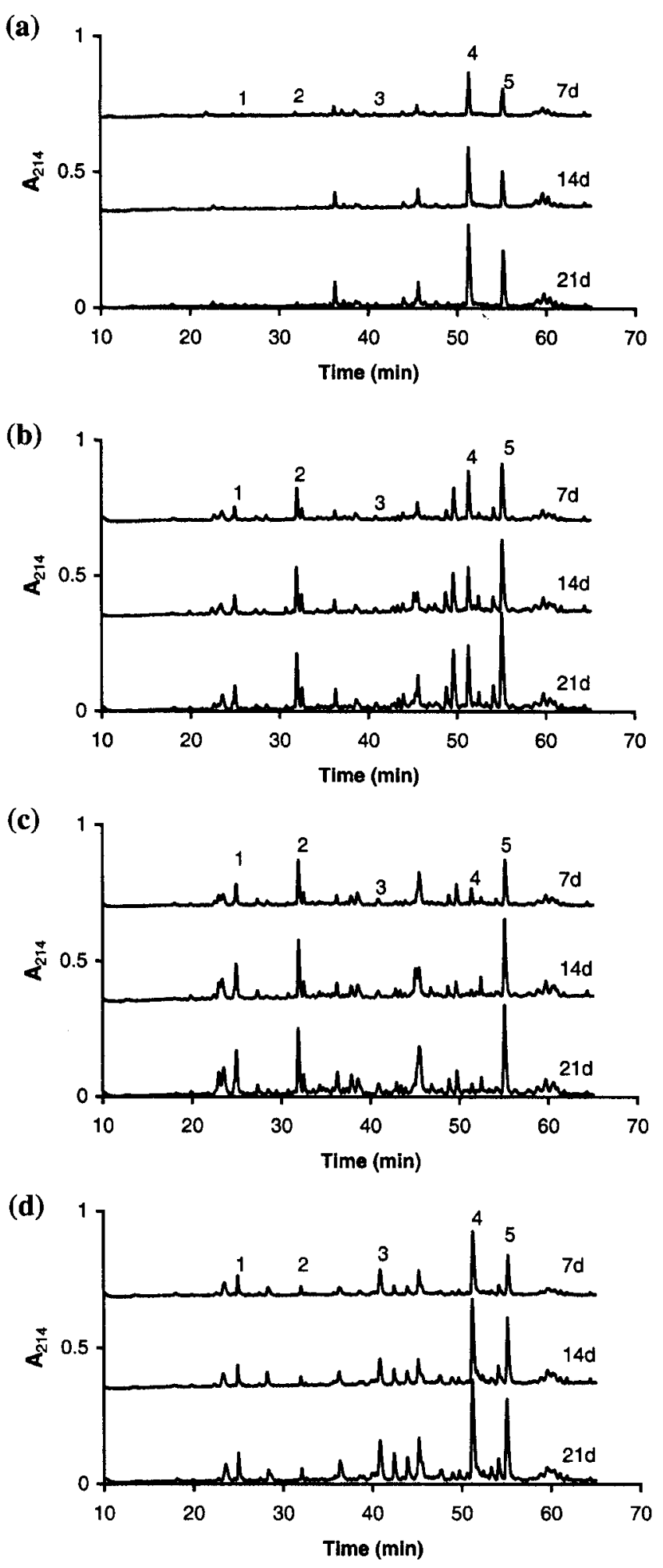

Figure 2. Chromatograms of water-soluble peptides from cheese made using (a) streptococci alone (control) or paired with a lactobacilli with different proteinase specificities (b) CI, (c) CIII, and (d) CV at $7 \mathrm{~d}, 14 \mathrm{~d}, 21 \mathrm{~d}$. Elution of known peptides is indicated as (1) $\alpha_{\mathrm{s} 1}-\mathrm{CN}$ (f 1-9), (2) $\alpha_{\mathrm{s} 1}$ - CN (f 1-13), (3) $\alpha_{\mathrm{s} 1}$ - CN (f 1-16), (4) $\alpha_{\mathrm{s} 1} \mathrm{CN}$ (f 1-23), and (5) $\beta$-CN (f 193-209). 
Table 2. Mean ${ }^{1}$ of various functional attributes of cheeses made using streptococci alone (control) or paired with a lactobacilli strain with different proteinase specificities.

\begin{tabular}{lcccc}
\hline & & \multicolumn{3}{c}{ Proteinase specificity } \\
\cline { 3 - 5 } Attributes & Control & I & III & V \\
\hline Melt (\%) & $58.1^{\mathrm{c}}$ & $73.2^{\mathrm{b}}$ & $74.2^{\mathrm{b}}$ & $81.9^{\mathrm{a}}$ \\
TPA-hardness (N) & $168.2^{\mathrm{a}}$ & $88.8^{\mathrm{bc}}$ & $101.5^{\mathrm{b}}$ & $80.3^{\mathrm{c}}$ \\
TPA-cohesiveness & $0.313^{\mathrm{ab}}$ & $0.338^{\mathrm{a}}$ & $0.289^{\mathrm{bc}}$ & $0.279^{\mathrm{c}}$ \\
Melt strength (N) & $3.17^{\mathrm{a}}$ & $2.02^{\mathrm{bc}}$ & $2.07^{\mathrm{b}}$ & $1.42^{\mathrm{c}}$ \\
Stretch quality (N) & $0.645^{\mathrm{a}}$ & $0.382^{\mathrm{b}}$ & $0.394^{\mathrm{b}}$ & $0.211^{\mathrm{c}}$ \\
Total water-soluble & & & & \\
peptides (mg/ml) & $1.10^{\mathrm{c}}$ & $2.39^{\mathrm{b}}$ & $2.98^{\mathrm{a}}$ & $2.66^{\mathrm{ab}}$ \\
\hline
\end{tabular}

a,b,c Means in rows with no common superscripts differ $(P \leq 0.05)$.

${ }^{1}$ Overall mean of data from $7 \mathrm{~d}$ to $21 \mathrm{~d}$. TPA = texture profile analysis.

ter-soluble peptides was lower in the control cheese than in treatment cheeses. Reduced proteolysis in control cheese is attributed to lowered MNFS (4\% less) and the relatively limited proteolytic ability of $S$. thermophillus. Total water-soluble peptides were similar in CI, CIII, and CV and increased $(P \leq 0.05)$ with age. Although CV had higher lactobacilli counts than the two other treatment cheeses $\left(10^{8}\right.$ vs. $\left.10^{6}\right)$, this had no apparent effect on the total water-soluble peptides that were produced.

\section{Meltability}

Among treatment cheeses, CI and CIII had similar values (73.2 and $74.2 \%$ ), while meltability of $\mathrm{CV}$ $(81.9 \%)$ was highest $(P \leq 0.05)$ (Table 2$)$. This difference was seen at 7,14 , and $21 \mathrm{~d}$ of age. Meltability of

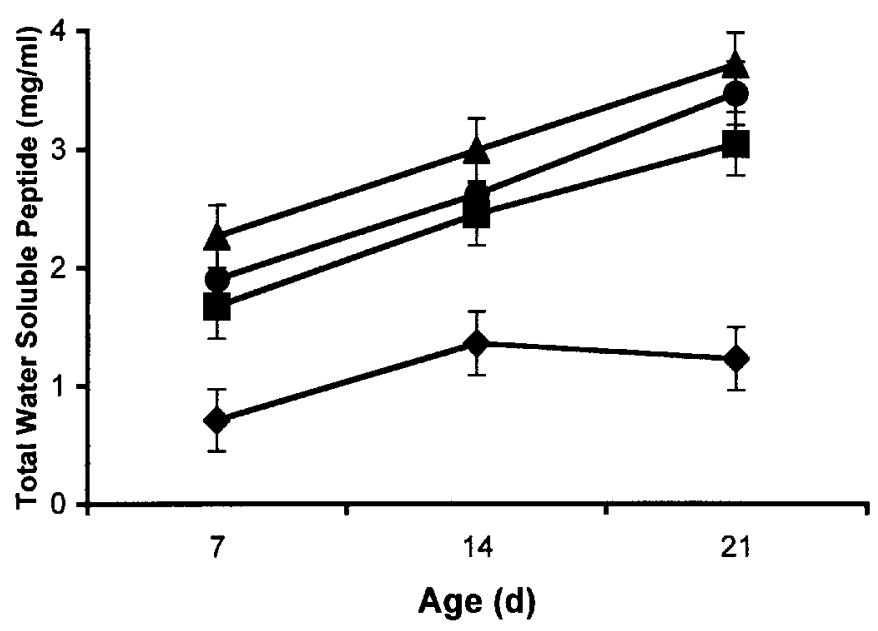

Figure 3. Total water-soluble peptides $(\mathrm{mg} / \mathrm{mL})$ in cheeses as a function of age $\bullet$ Control, $\mathbf{a C I}, \mathbf{\Delta C I I I ,} \boldsymbol{C C V}$. Error bars represent $\mathrm{SEM}=0.265$. cheese increased $(P \leq 0.05)$ with age (Figure 4$)$. This aging effect may be attributed to breakdown of the $\mathrm{CN}$ matrix, release of calcium, or to increased $\mathrm{CN}$ hydration that occurs in cheese with proteolysis (Lawrence, 1987). When comparing the effect of proteolysis on melting, it is not just a simple matter of the cheese with the most proteolysis having the most melt. In this experiment, the cheese with the highest melt was $\mathrm{CV}$, but the cheese with the highest level of total water-soluble peptide was CIII. Both CIII and CI had equivalent melts but the extent of proteolysis was significantly lower in CI than in CIII (see Table 2). These differences in melt may be due to differences in the protein hydrolysis occurring in different parts of $\mathrm{a}_{\mathrm{s}}$ and $\beta$-CN (Bogenrief and Olson, 1995; Dave et al., 2001). Thus, the differences in melt seen in this experiment are not only due to the total proteolysis but also to the specificity of proteolysis occurring in different parts of the CN molecule.

\section{Texture Profile Analysis}

The three cheeses made using lactobacilli (CI, CIII, and CV) were all softer than the control cheese (Table 2 and Figure 5). There was less proteolysis in the control cheese, but attributing the increased hardness to proteolysis is confounded by the lower moisture content. The increased hardness of the control cheese may be attributed to those factors (Green et al., 1981). At $7 \mathrm{~d}$, there were no differences between the experimental cheeses, but by $21 \mathrm{~d}$, there were some significant differences and CIII increased in hardness while no change (or slight decrease) occurred in CV.

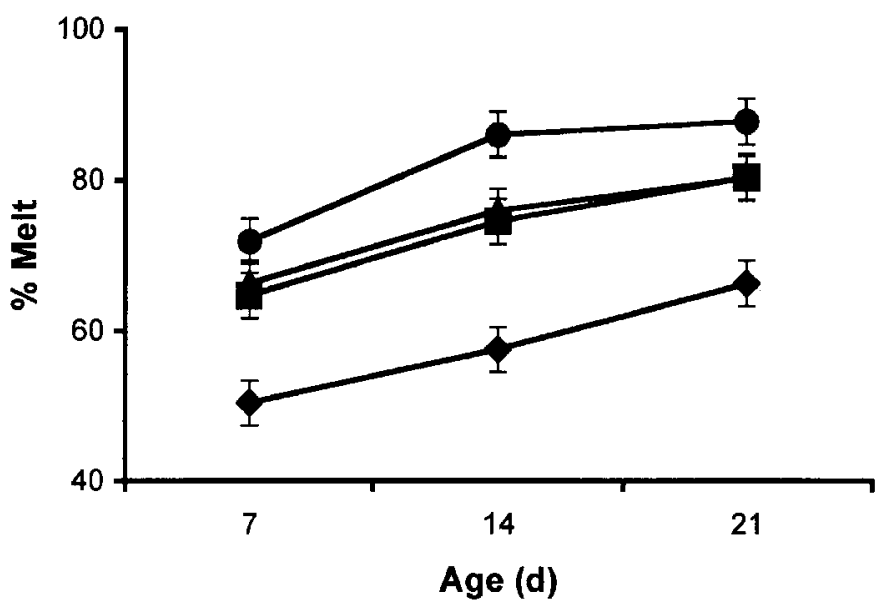

Figure 4. Meltability of cheeses made using streptococci alone (control) or paired with a lactobacilli strain ( Control, $\square$ CI, $\Delta$ CIII, -CV) with different proteinase specificities during its storage for 21 d. Error bars represent SEM. 


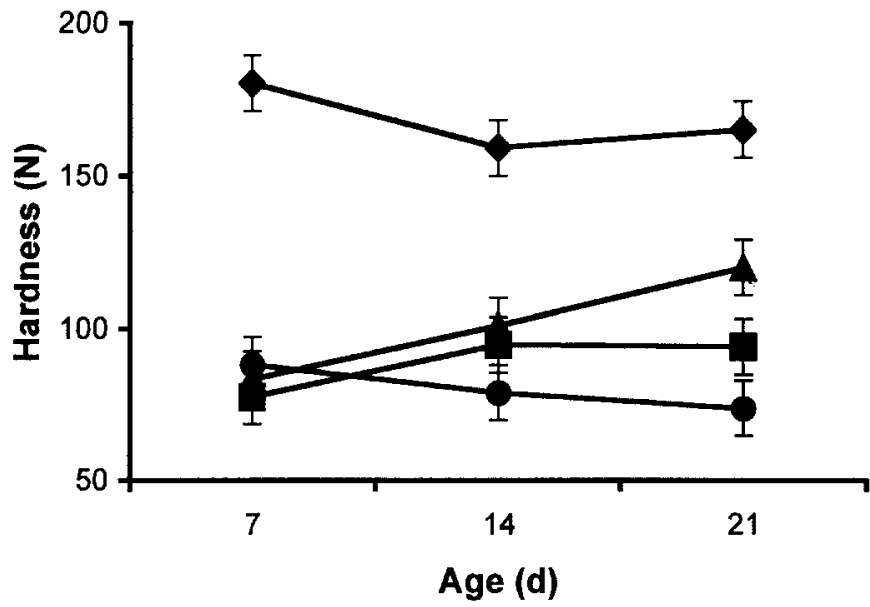

Figure 5. Texture profile analysis-hardness of cheeses made using streptococci alone (control) or paired with a lactobacilli strain ( Control, $\square \mathrm{CI}, \boldsymbol{\Delta} \mathrm{CIII}, \mathbf{C V}$ ) with different proteinase specificities during its storage for $21 \mathrm{~d}$. Error bars represent SEM.

There were some minor differences in cohesiveness of the cheeses, with CV having the lowest cohesiveness (Table 2). Cohesiveness of all cheeses increased from an average of 0.270 at $7 \mathrm{~d}$, to 0.359 at $21 \mathrm{~d}$. The differences in hardness and cohesiveness may be a function of the different protein hydrolysis profiles of the cheese.

\section{Stretchability}

Melt strength of the cheeses has been correlated to viscosity of the molten cheese (Fife et al., 2002). Melt strength was highest $(P \leq 0.05)$ for the control cheese and lowest $(P \leq 0.05)$ for $\mathrm{CV}$ (Table 2 and Figures 6,7$)$. The control cheese was expected to have a higher melt strength because of its lower moisture. The lower melt strength of CV corresponds to its lower hardness. Melt strength of the experimental cheeses decreased $(P \leq 0.05)$ during storage which is in agreement with decreases in melt viscosity that have previously been reported (Oberg et al., 1991; Fife et al., 1996). Melt strength remained constant $(P>0.05)$ in the control cheese with age and can be related to the limited proteolysis that occurred due to the lack of lactobacillal component in the starter culture. In general, the load exerted during stretching of the cheese was proportional to melt strength.

Similarly, stretch quality was highest $(P \leq 0.05)$ for the control cheese $(0.644 \mathrm{~N})$ and lowest $(P \leq 0.05)$ for CV $(0.211 \mathrm{~N})$ (Table 2 and Figure 8). There were no significant differences in stretch quality between CI and CIII. Stretch quality decreased $(P \leq 0.05)$ with age from $0.616 \mathrm{~N}$ at $7 \mathrm{~d}$ to $0.260 \mathrm{~N}$ at $21 \mathrm{~d}$ for all

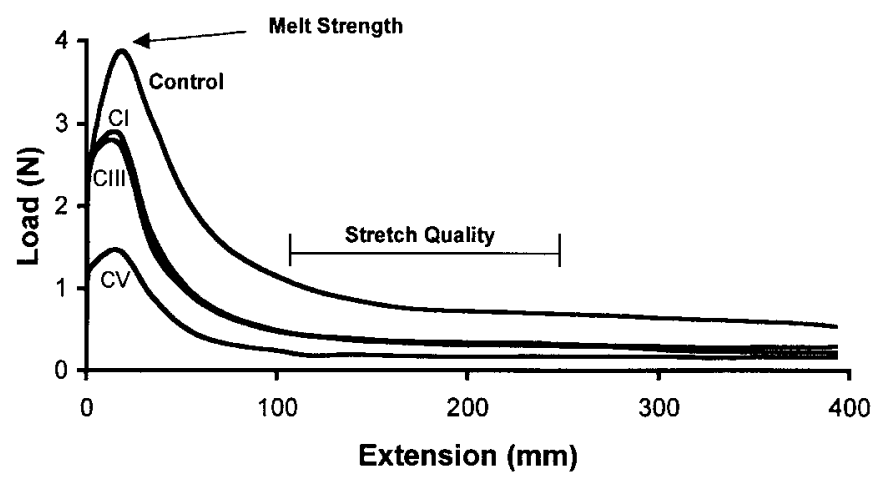

Figure 6. Stretch test profile of cheeses made using streptococci alone (control) or paired with a lactobacilli strain (CI, CIII, CV) with different proteinase specificities at $14 \mathrm{~d}$ of storage using Utah State University stretch test. Melt strength is the peak load during the tensile strength, and stretch quality is the area under the curve from 115 to $250 \mathrm{~mm}$ of extension.

cheeses. Stretch quality describes the ability of the cheese strands to remain together as a cohesive mass while being pulled. A decrease in stretch quality coupled with a reduction in viscosity of cheese during storage is typical of Mozzarella cheese. All of the cheeses stretched the full length of the test $(30 \mathrm{~cm})$ implying that the stretch lengths were similar.

Overall, melt strength and stretch quality were both negatively correlated with the percentage of watersoluble peptide content of the cheeses with $R^{2}$ values of 0.55 and 0.64 , respectively. When treatments were separated and cheeses analyzed individually, the variation in melt strength and stretch quality could be better explained $\left[\mathrm{R}^{2}\right.$ values of $0.87(\mathrm{CV})$ to $0.93(\mathrm{CI})$

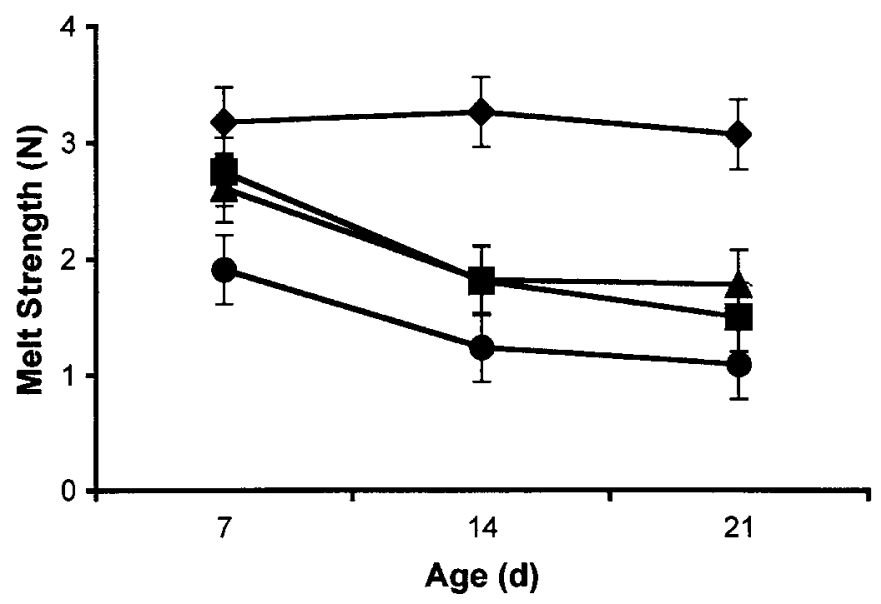

Figure 7. Melt strength of cheeses made using streptococci alone (control) or paired with a lactobacilli strain ( Control, $\square$ CI, $\Delta$ CIII, oCV) with different proteinase specificities during its storage for 21 d. Error bars represent SEM. 
for stretch quality and 0.80 (CIII) to 0.96 (CI) for melt strength] as a function of total water-soluble peptides. Thus, while overall extent of proteolysis affects the stretch properties of cheese, the individual proteolytic patterns were also important contributors to cheese functionality.

Lactobacilli with different proteolytic specificities can be used to make cheese with different functional properties even when the amount of total proteolysis is similar. Cheese made with the group V culture had lower melt strength, lower stretch quality, and higher meltability than the other cheeses even though the amount of water-soluble peptides in the cheeses was similar. Thus, the pattern of protein hydrolysis in cheese, which can be linked to the diversity of proteinases among lactobacilli, should be considered an important indicator of functional qualities such as stretch, meltability, and melt strength of these cheeses. It must also be acknowledged that the differences in the functional properties among the treatment cheeses may be a result of unobserved hydrolysis occurring elsewhere on the protein molecule.

\section{CONCLUSION}

In conclusion, water-soluble peptide profiles of cheeses made using strains of lactobacilli that had different specificities toward $\alpha_{\mathrm{s} 1}-\mathrm{CN}$ (f 1-23) paralleled profiles obtained when the cultures were tested in vitro. Thus, the breakdown of proteins in cheese can be controlled through strain selection among lactobacilli. Earlier investigations have explored the influence of proteolysis on functional properties by examining dis-

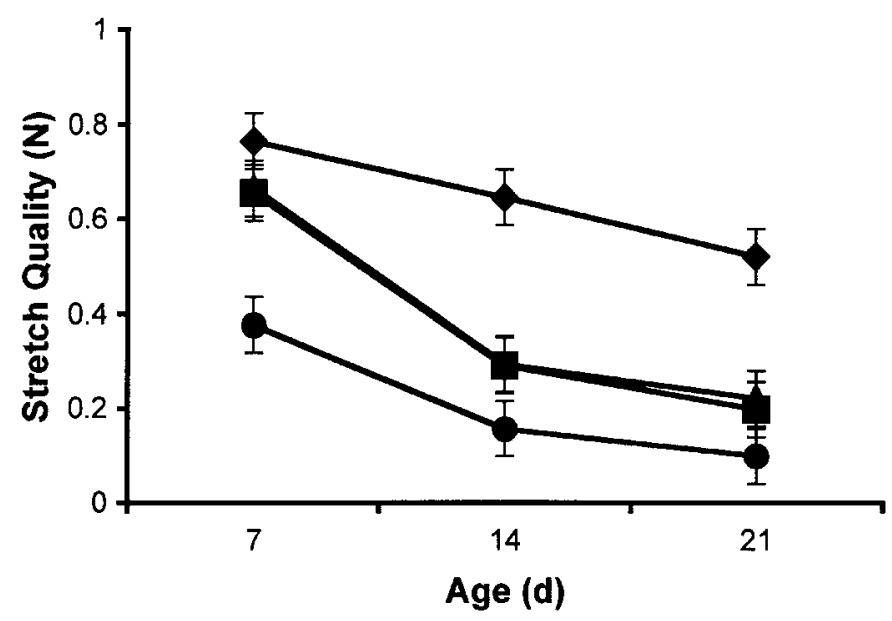

Figure 8. Stretch quality of cheeses made using streptococci alone (control) or paired with a lactobacilli strain ( Control, $\square$ CI, $\Delta$ CIII, -CV) with different proteinase specificities during its storage for 21 d. Error bars represent SEM. appearance of intact proteins or extent of overall proteolysis. This study demonstrated that differences in cheese functional properties such as hardness, melt, and stretch can be influenced by differences in lactobacilli protease specificity. Protein specificity of the lactobacillal component should be considered when selecting starter culture strains to manufacture cheeses with defined functionality. The aim of future research should be to determine the specific bonds in $\mathrm{CN}\left(\alpha_{\mathrm{s} 1^{-}}\right.$ $\mathrm{CN}, \alpha_{\mathrm{s} 2}-\mathrm{CN}$, and $\beta-\mathrm{CN}$ ) that when hydrolyzed result in a change in functional properties of cheeses.

\section{ACKNOWLEDGMENTS}

This research was funded by Dairy Management Inc. and the Utah Agricultural Experiment Station

\section{REFERENCES}

Association of Official Analytical Chemists. 1990. Official Methods of Analysis. 15th ed. AOAC, Arlington, VA.

Bogenrief, D. D., and N. F. Olson. 1995. Hydrolysis of $\beta$-casein increases Cheddar cheese meltability. Milchwissenschaft 50:678-682.

Broadbent, J. R., M. Strickland, B. Weimer, M. E. Johnson, and J. L. Steele. 1998. Peptide accumulation and bitterness in Cheddar cheese made using single strain Lactococcus lactis starters with distinct proteinase specificities. J. Dairy Sci. 81:327-337.

Dave, R. I., D. J. McMahon, C. J. Oberg, and J. R. Broadbent. 2002. Influence of coagulant concentration on proteolysis, meltability and rheology of Mozzarella cheeses made using direct acidification. J. Dairy Sci. (Accepted).

Exterkate, F. A., and A. C. Alting. 1993. The conversion of the $\alpha_{\mathrm{s} 1^{-}}$ Casein-(1-23)-fragment by the free and bound forms of the cell envelope proteinase of Lactococcus lactis subsp. cremoris under conditions prevailing in cheese. Syst. Appl. Microbiol. 16:1-8.

Exterkate, F. A., A. C. Alting, and P. G. Bruinenberg. 1993. Diversity of cell envelope proteinase specificity among strains of $\mathrm{Lac}$ tococcus lactis and its relationship to charge characteristics of the substrate-binding region. Appl. Eviron. Microbiol. 59:3640-3647.

Fife, R. L., D. J. McMahon, and C. J. Oberg. 1996. Functionality of low fat Mozzarella cheese. J. Dairy Sci. 79:1903-1910.

Fife, R. L., D. J. McMahon, and C. J. Oberg. 2002. Test for measuring stretchability of melted cheese. J. Dairy Sci. 85:3206-3213.

Fox, P. F. 1989. Proteolysis during cheese manufacture and ripening. J. Dairy Sci. 72:1379-1400.

Green M. L., A. Turvey, and D. G. Hobbs 1981. Development of structure and texture in Cheddar cheese. J. Dairy Res. 48:333-355.

Juillard, V. H. Laan, E. R. S. Kunji, C. M. Jeronimus-Stratingh, A. P. Bruins, and W. N. Konings. 1995. The extracellular PItype proteinase of Lactococcus lactis hydrolyzes $\beta$-casein into more than one hundred different oligopeptides. J. Bacteriol. 177:3472-3478.

Kunji, E. R. S., I. Mierau, A. Hagting, B. Poolman, and W. N. Konings. 1996. The proteolytic systems of lactic acid bacteria. Antonie van Leeuwenhoek 70:187-221.

Lawrence R. C. 1987. The use of ultrafiltration technology in cheese making, IDF Document B 136, Int. Dairy Fed., Brussels, Belgium.

Oberg, C. J., J. R. Broadbent, M. Strickland, and D. J. McMahon. 2002. Diversity in specificity of the extracellular proteinases in Lactobacillus helveticus and Lactobacillus delbrueckii subsp. bulgaricus. Lett. Appl. Microbiol. 34:455-460. 
Oberg, C. J., A. Wang, L. V. Moyes, R. J. Brown, and G. H. Richardson. 1991. Effects of proteolytic activity of thermolactic cultures on physical properties of Mozzarella cheese. J. Dairy Sci. 74:389-397.

Richardson, G. H., ed. 1985. Pages 371-376 in Standard Methods for the Examination of Dairy Products. 15th ed. Am. Publ. Health Assoc., Washington DC.

SAS User's Guide: Statistics version 6.0. 1990. SAS Inst., Inc., Cary, NC.
Tunick, M. H., K. L. Mackey, J. J. Shieh, P. W. Smith, P. Cooke, and E. L. Malin. 1993. Rheology and microstructure of low-fat Mozzarella cheese. Int. Dairy J. 3:649-662.

van Vliet, T. 1991. Terminology to be used in cheese rheology. Pages 5-15 in Rheological and Fracture Properties of Cheese. IDF Bulletin No. 268. Int. Dairy Fed., Brussels, Belgium.

Wang, Y.-C., K. Muthukumarappan, M. M. Ak, and S. Gunasekaran. 1998. A device for evaluating melt/flow characteristics of cheeses. J. Texture Stud. 29:43-55. 